\title{
Effect of Bank Capital Requirements on Bank Risk-taking and Financial Stability
}

\section{Phd Candidate Aida Mosko}

\author{
Lecturer, University “Fan S. Noli”, Albania; aida.mosko@yahoo.com
}

\author{
Prof. Ass. Dr. Anilda Bozdo
}

Professor, European University of Tirana, Albania; anildabozdo@gmail.com

\author{
Doi:10.5901/mjss.2016.v7n1p340
}

\begin{abstract}
This paper reviews theoretical and empirical studies on the way that capital requirements influences bank capital structure, risktaking and lending. Deposit insurance, when not fairly priced, give incentives for excessive risk-taking. To alleviate this problem regulator found as necessary the use of certain requirements such as capital requirement. Based on this, it is obligatory for banks to hold more capital that means to have more of their own funds at risk. The theoretical literature related to the way how capital regulation influences banks on their decision for the capital structure and portfolio risk says more than that. Capital requirements were supposed to enhance financial stability and economic growth. Regarding economic growth, the effects of capital requirements can influence it directly or indirectly. Changes that capital requirements bring to the credit supply, costs of capital and to the bank asset risks affect indirectly the economic growth. Higher capital requirements reduce credit supply and decreases credit demand which in turn may slow down economic growth. Nevertheless, well-capitalized banks make provision of credit more consistent and enhance financial stability. Suggestions given from the theoretical literature and lessons learned from empirical researches are going to be used in analyzing effects of bank capital requirements on the relation between efficiency, capital and risk-taking in Albanian banking system
\end{abstract}

Keywords: bank capital, bank regulation, financial stability.

\section{Introduction}

During 1970s banking sector has been subject of deregulation. This includes taking off the interest rate ceiling, the restrictions on lending, on the kind of financial activities that they could be involved. Even though at the beginning the impact of deregulation influenced positively the performance of real economy at the same time facts tells us that the banking crises have been increased. Facing this situation, regulators found as necessary the use of certain requirements to compete with free banking. As such, the capital requirements were first used through the maximum leverage ratios. To make possible reduction of insolvency chances, regulations on capital were implemented.

Toward the tendency of banks to take high level of risks, regulators settled links between capital required and the risk of loan portfolio. The first Basel Accord (the international initiative for recommendations on banking regulations), by 1988, was focused on capital regulation. Based on the shortcomings of this accord comes the second one that brings three pillars without putting aside the calculation of minimum capital requirements. Three pillars of second accord consist of: minimum capital requirement, supervisory review process and market discipline.

In the context of financial stability is released Basel III accord. According to it, higher bank capital through reduction of banks' financial inconveniency and minimization of losses given default, will increase financial stability.

Along with these supervisory and regulatory accords two questions are raised. What is the influence of capital regulation on bank efficiency and probability of failure? What are the impacts that these supervisory and regulatory accords will have to the economy?

The paper is organized as follow: Session 2 gives a summary of theoretical and empirical literature on the efficiency of capital regulation and effects that might have capital regulation on the bank's decision. These studies give contradictory results. Theoretical models are supposed to give answer to a certain questions linked with model-specific assumptions. Session 3 provides an overview of the literature on the different effects that capital regulation has on economic growth. Researches on the impact that capital regulations has to the economy come to the conclusion that Changes that capital requirements bring to the credit supply, costs of capital and to the bank asset risks affect indirectly the economic growth. The fourth session gives an overview of capital regulation in Albanian banking system. Suggestions 
given from the theoretical literature and lessons learned from empirical researches are going to be used in analyzing effects of bank capital requirements on the efficiency of Albanian banking system. The fifth session gives conclusions of the paper.

\section{Capital Regulation Influences on Capital Structure and Risk-taking Decisions}

Efficiency of capital regulation on decision making about capital structure and risk-taking has been part of theoretical and empirical literature. An overview of the way that capital regulation affects bank efficiency and reduce the probability of failure will be given by summarizing these literatures.

\subsection{Characteristics of bank capital}

The main components of a financial institution capital are retained earnings and funds from issuing stock. It serves as a financing tool by buffering losses that can jeopardize bank solvency. In this context, bank capital functions as a protection tool and gives incentives for prudential management because in case of bankruptcy, shareholders capital is at risk. Banking capital is important not only in microeconomic level, insurance of individual banks, but also in macroeconomic level, insurance of banking system. Most of its activity is funded by deposits and other kinds of borrowing which have to be fully paid. A well capitalized bank, even though for a certain period is experiencing losses and reduction of base capital, will still remain with a positive balance towards solvency.

Two other important characteristics of capital have to be mentioned. First, banking capital differently from banking obligations is permanent. As long as bank's activity continues, there is no obligation for it to pay back the initial investment to the investors. They are the last to be paid after obligations to all creditors are fulfilled. Secondly, distributions to capital investors are not obligatory and usually differ in accordance with profits ensured by bank. On the other side, on long run they expect higher returns than investors on debt securities.

Definition of capital is linked with three main concepts of it:

Actual capital, which is related to the physic capital and in the balance sheet is represented by equity and long term debts. It is measured by the capital ratio (ration of equity to total assets)

Regulatory capital, or risk weighted capital. It is the siza of capital defined by rules of supervisory authorities. It is measured by risk based capital ratio: ratio of capital to risk-weighted assets

Economic capital, the maximum capital need for a normal operation of banks bussines based on its strategy.

\subsection{Literature review}

As stated above the bank capital regulation is very important. The regulators have to find the right solution between risk of default and capital level. In theory, it is not clear the impact that capital regulation might have on bank risk-taking. Both theoretical and practical studies do not give a final conclusion whether more capital requirements reduce bank's risktaking and increase safety on lending.

\subsubsection{The Modigliani-Miller theorem}

According to Modigliani and Miller theory (their seminal contribution in 1958) firm's earning power and the risk of its underlying assets lays down its market value. This market value is independent by the way how the firm finances its investments and also by the way it chooses to distribute dividends. The basic idea of this theorem is that doesn't make any difference whether investments of a firm are financed with equity of debt. This applies in terms of complete financial markets and perfectly informed depositors about bank's risk to failure. Since the contribution of Modigliani and Miller (1958), researchers have studied how to reach an optimal capital structure by implications of deviations from the frictionless world that they assumed in their theory. Researchers started to study the role of capital regulation in incomplete market settings. Bank operates as a corporation. As such its owners liabilities are limited to their investments, shareholders' loss are limited while every amount over the amount owed to depositors is all theirs. It is because of this that banks prefer risky to save investments. On the other side, in case of perfectly informed depositors about banks' strategy on investments, they would claim interest rates related to the bank's risk level. Shareholders seek maximization of their share value. Due to the impossibility of exploiting their controlling position, the aim of maximizing share value becomes equivalent to maximize the bank's total value. Thus, the portfolio chosen is the one that maximize the value and the capital structure has no influence on bank's market value. In this context, there would be no need for regulation since 
banks would choose optimal risk levels.

\subsubsection{Information advantages, deposit insurance and moral hazard}

Under the assumptions of Modigliani-Miller theorem (complete markets and absence of disagreements) there is no place for banks. Information advantage on monitors is crucial for a bank. For this reason depositors cannot make an assessment of bank's risk. They lack the information needed and this information advantage arises moral hazard.

Jensen and Meckling (1976) brought the concept of "agency theory". They emphasize the conflict of interest between different contracting parties, principals and agents that are shareholders (owners), managers and equity holders. Since their seminal work, a vast literature can be found on explanations given to the nature of these conflicts of interests and also on the methods to solve them. According to Jansen and Meckling (1976), the agency relationship can be defined as a contract between the principal and the agent. The entire cost of failure on pursuing goals is hold by managers while they can have only a fiction of the benefits.

Jensen and Meckling defined an agency relationship as:

"... a contract relationship which one or more persons (the principal) engage another person (the agent) to perform some service on their behalf which involves delegating some decision making authority to the agent. If both parties to the relationship are utility maximizes, there is good reason to believe that the agent will not always act in the best interests of the principal."

By using the term of utility it is highlighted that individuals may work and/or to increase also non-monetary activities that will serve to the increase of utility.

The moral hazard is present in the case of deposit insurance with full cover. This kind of deposit insurance does not reflect the asset risk and in this way banks have the incentives to increase riskiness of their portfolio. Benson et al. (1986) and Kane (1985) has analyzed the way how fixed-rate insurance stimulates risk-taking by banks. Merton (1977) and other authors have studied moral hazard due to deposit insurance. The extreme implication of it is in the case of zombie banks (Kane 1989).

Literature disagrees on positive effects that capital regulation might have on reduction of moral hazard due to fixedrate deposit insurance. To limit the probability of failure in such situation (fix-rate deposit insurance) asset portfolio regulation has to be associated with capital requirements. But, there also views that oppose this. Furlong and Keely (1989) find out that under state-preference and option pricing models and deposit insurance, the incentive to increase risk and leverage counts on the level of risk and leverage. More strict capital regulation will diminish moral hazard and the probability of bank failure will have the same trend.

\subsubsection{Portfolio models}

During its operation, bank aims to achieve maximization of a von Neumann-Morgenstern utility function. This function is a description of preferences that risk-averse owner-manager has and also it reflects bank's objective. Harry Markowitz worked on a classical mean-variance approach to treat the dilemma: the contradictory objectives of high profit on one side and low risk on the other. This model was sufficiently general for a single period framework and simple for theoretical analysis.

The effect of flat capital regulation is analyzed by Koehn and Santomero (1980). The relation between the level of required capital and loss in expected returns is positive. Because of these losses banks have the incentive to invest on higher risk assets. The increase of risk-taking and related to this the change on probability of failure is connected to the degree of risk aversion. Koehn and Santomero find that it is not possible to reduce the probability of failure only by applying capital requirements. Capital regulation has to be compounded with asset regulation.

\subsubsection{Managerial moral hazard}

Bank's actions are executed in accordance with shareholders interests through the assumption that shareholders control the bank or managers act on their behalf. However, under the view of interests, managers and shareholders are different. Sounders, Strock, and Travlos (1990) analyze the relation between risk taking and ownership structure. They found that manager controlled banks (banks whose managers hold relatively small portion of bank's stock) manifest lower risk taking attitude than stockholder controlled banks (banks whose managers hold relatively high portion of bank's stock). 
Ownership structure effects more risk banks in periods of deregulation then in periods of regulation. Anderson and Fraser (2000) link the relationship between managerial ownership and bank risk-taking behavior with the charter value of banks. They found it positive at low charter value in periods of deregulation and negative during periods of re-regulations.

Dewatripont and Tirole (1994) bring the "representation hypothesis". Arguing the managerial moral hazard within a bank and the lack of knowledge on shareholders, they stand to the need of another institution, the regulator, to take over the control. In case that bank's solvency falls under certain levels, capital regulation gives support to optimal banking governance structure. In case of falling below capital requirements the solvency requirements will increase. To avoid this, managers have the incentive to monitor the assets and by doing this they avoid the possibility of lowering portfolio risk. This shows that capital requirements influence the decrease of default risk.

\section{Capital Regulation Influences on Economic Growth}

This section gives an overview of the literature assessing effects of capital regulation on economic growth. Except this, the way how banks meet capital requirements is really important.

Along with the supervisory and regulatory accords comes up the question whether these constraints on capital will really bring positive impacts to the economy. It is possible that banks, because of capital regulation, reduction of credit, increasing of lending rates transmit a negative impact to the economy.

From the literature point of view, capital regulation can have different effects on the real economy. Evidences show a limited direct link between capital regulation and economic growth, while the indirect impact of regulation on cost of capital, credit level and asset risk influences economic growth.

Country economic growth process is preceded and supported by the financial system. Well-functioning of banking institutions (indicated by bank efficiency) has a positive impact to the economic growth. According to this, the relationship between risk and capital has to be viewed in the frame of bank efficiency (indicator of bank performance). In addition to this bank capital is likely to be linked with bank cost efficiency, loans to total asset, earnings, ratio of off-balance-sheet items to total assets, and bank size.

\subsection{Financial stability}

The main argument that stands behind Basel III is related to the role that bank capital has on financial stability. Financial stability is influenced by: 1) the probability of banks financial distress; and 2) banks' losses on given default. By reducing the probability of the first one and minimizing losses on the second financial stability will be enhanced. Capital regulation transmits its effects to financial stability through reduction of bank's risk-taking incentives and higher capital.

As a consequence of information asymmetry between bank shareholders and bank depositors of in other words as a result of limited liabilities for shareholders and financial safety net for bank depositors, risk-taking is encouraged. This incentive is reduced by the restrictions of capital requirements. Santos (1999), by applying an approach with two sources of moral hazard, finds out a positive impact of capital regulation on bank's stability.

The influence of capital regulation on bank's stability is studied also in macroeconomic level. The aim of these studies has been finding of macroeconomic effects of higher capital requirements. According to Martinez-Miera and Suarez (2014) capital requirements affect the cost and frequency of systemic crises. This is achieved through support that capital requirements give in reducing systemic risk-taking.

In the studies presented so far results that higher capital requirements improve bank's stability and decrease costs and frequency of systematic crisis. Even so, there are contradictory arguments to these conclusions. It may result on higher bank's incentive to risk-taking if more rigorous capital regulations are applied. In the frame of profitability, higher capital requirement result on lower profits, which reduces bank's franchise value that is defined as the net present value of banks future profits. Protection of franchise value provides a risk-constraining incentive to banks. Marcus (1984) develops Franchise Value Theory (FVT). According to this theory relationship between franchise value and firm risktaking is negative. The same results on the empirical evidences of Keeley (1990) and Demsetz et al., (1997). The increase on risk-taking incentives devaluate the effect of capital regulation.

The contradictory conclusions can be found on empirical studies. There are conclusions that support the hypothesis of reductions on "capital and asset risk" because of capital regulation as well as conclusions against it.

Related to the relation between bank capital level and riskiness bank assets, most empirical evidence concludes that higher bank capital lower its riskiness assets. Kashyap et al. (2010) finds a positive connection between leverage and equity risk. De Jonghe (2010) studied systemic risk exposure and found out that bank's exposure to systemic risk is reduced by higher capital. Miles et al. (2012) comes to the same conclusion while using Capital Asset Pricing Model 
(CAPM) to estimate the connection between leverage and levered beta. According to this study higher capital reduces the probability of banking crises.

There are also empirical evidences in the frame of capital requirements impact on bank risk-taking. De Haan and Klomp (2012) studied 25 indicators of banking risk for 200 banks operating in 21 OECD countries. They also studied these indicators (2015) for banks operating in emerging and developing countries. Both studies report a positive impact of capital regulations on "capital and asset risk" of banks. They found this relation stronger in case of low capitalized or riskier banks.

However, most of studies on this issue bring opposite conclusions. They report a weak connection between capital requirements and bank risk.

Summarizing theoretical and empirical studies on the impact that strict capital requirements have on risk-taking, both of them do not give a final conclusion.

According to Matten (1996) three are the main functions of bank capital. In the frame of financial stability, the focus will be on its risk sharing function (loss-absorbing function), that is one of the principle functions of capital. Capital provides a buffer to cover any losses. High level of capital enables bank to absorb losses resulting from borrower's defaults and from situations where assets are partly or entirely irrecoverable.

By analyzing under-capitalized banks and well-capitalized one for their attitude towards landing, results that lending reduction is higher in undercapitalized banks. Bernake and Lown (1991) found for the period 1990-1991, a positive relation between loan growth and bank's capital ratios in both state level and individual banks level. Woo (2003), while analyzing supply factors standing behind the credit slowdown In Japan in 1997, found as such the shortage of bank capital. According to his research, there is a positive relationship between bank lending and regulatory capital. Haubrich and Wachtel (1993) analyzing, based on capital requirements of the Basel Accord, shifting within each asset category and substitution effects found out that banks with low-capital ratio are shifting high risk weighted assets with lower risk weights. Albertazzi and Marchetti (2010) found that contraction of credit supply for the period 2007-2009 is related to the low bank capitalization and scare liquidity. Kapan and Minoiu (2013) conclude that bank capital played a protective role: banks with lower leverage ratio that were exposed to the financial market shocks showed a lower decrease on supplying credit than other banks.

All studies referred in this section indicate that the higher capital the more stable is the provisioning of credit.

Gambacorta and Mistrulli (2004) studied how GDP shocks influences lending. Banks lending behavior has been studied depended on their level of capitalization. They used data for Italian banks, for the period 1992-2001, and found out that well-capitalized banks can better absorb transitory hard financial situations on the part of their borrowers and keep long-term lending connection.

In the case of monetary shocks, results are the same for well-capitalized banks. Bank loan supply differs according to bank's asset size and capital leverage ratio Kishan and Opiela, (2000). Well-capitalized banks can protect their lending because they have easier access to non-insured funding. For banks with lower capital the negative impact of monetary shocks (higher interest rates) on crediting activity is stronger. Jumenez et al. (2012) show that loan supply and demand is influenced by monetary policy and the economic situation. Furthermore, loan granting is substantially reduced by banks with lower capital (less capitalized).

Bank capital influences bank's financial stability and their ability to survive during financial crises.

Along with studies that support such role of bank capital on financial stability, there are studies that come to a different conclusion for banks of developed countries during the 2008 crisis. Huang and Ratnovski (2009), based on OECD data, found no relation between bank capital of banks before crises and their performance during crisis. In this way, it cannot be given a definite conclusion whether bank capital will always expand financial stability.

\section{Bank Capital Regulation in Albania}

The starting point of current Albanian banking system is year 1998, when first private banks became part of it. In 2015 there are 16 banks operating in Albania which provide services like: deposits, accounts, transfers, loans, e-banking, etc. in a competitive environment. The services offered by Albanian banks are comparable to the ones offered in more developed countries. Analyzing data's on table 1, it is obvious the growth of the total assets and the progress that the Albanian banking system has made for the period 2009 - 2014. The ratio of total assets to GDP, which is used as an indicator for this presence, has an upward trend for the period 2009-2012. During 2013 the banking system's presence in the economy, measured by the increase of total assets share to the Gross Domestic Product, continued to grow, maintaining the trend manifested over years. Conversely, the ratio of loans to Gross Domestic Product dropped due to the fall in total loans. During 2014 the ratio of total credits/GDP has been increased compare to a year earlier. This is by 
the increase of credit higher than the increase of GDP. The increase of credit portfolio shows the importance of crediting in the economy of Albania.

Table 1. Weight of assets and credit portfolio to GDP

\begin{tabular}{|l|c|c|c|c|c|c|}
\hline Indicators & $\mathbf{2 0 0 9}$ & $\mathbf{2 0 1 0}$ & $\mathbf{2 0 1 1}$ & $\mathbf{2 0 1 2}$ & $\mathbf{2 0 1 3}$ & $\mathbf{2 0 1 4}$ \\
\hline Total assets (in mld ALL) & 886.3 .30 & 990.60 & $1,120.20$ & $1,187.98$ & $1,187.98$ & $1,293.72$ \\
\hline Total assets/GDB (in\%) & 77.50 & 81.00 & 86.10 & 89.61 & 91.13 & 91.56 \\
\hline Total credit/GDP (in\%) & 39.3 & 40.10 & 40.00 & 43.58 & 41.80 & 42.12 \\
\hline
\end{tabular}

\section{Source: Bank of Albania}

Albanian banking system provides universal banking services and in this way it has an important role on setting up a solid infrastructure by supporting the savings and investments in the economy. Referred to figure 1, for the period 2006 - half of 2015, the total assets of the Albanian banking system has been accelerated. The banks' asset structure continued to be financed mainly by household deposits and was focused on lending, primarily to the private sector. The shareholder's equity has been also following an upward trend with a slower growth from previous years. Consequently, in 2010, banking activity continued to deepen its intermediation in the economy. This intermediation indicator, banking system total assets to the GDP, has been increased from one year to the other although it has to be mention that the marginal growth is decreasing from 2011, coming to 0.43 percentage annual growth in 2014. This annual increase in comparison with previous year is: 3.5 percentage points in 2010 compared to $2009,5.1 \%$ percentage point in 2011, 3.5 percentage point in 2012, 1.5 percentage point in 2013 and 0.43 percentage point in 2014.

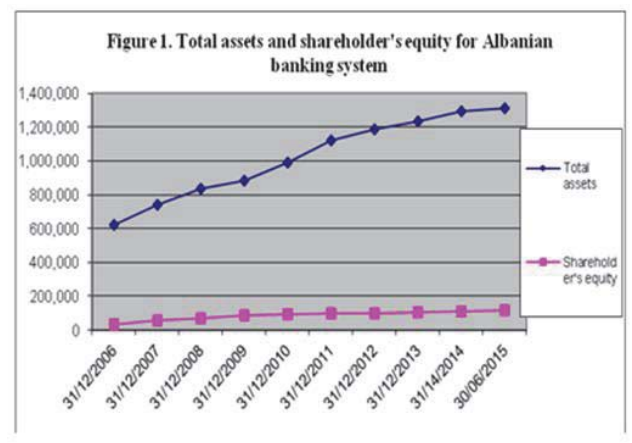

The credit growth and the country's economic growth have been moving together in the same directions. There are evidences for Albania that there is a bi-directional relationship between financial development and economic growth in the long-run. For the period 2006-2011 the acceleration of lending is result of macroeconomic conditions and the demand of the economy for credit. The lower growth of risk-weighted assets made major contribution to banks' capitalization during this period. Concerns relating to loan quality and the lower market rates reduced the banking sector's positive profit further. There is, therefore, less room for the banking sector to generate sufficient income that would support the increase in capital and conduct operations through domestic resources.

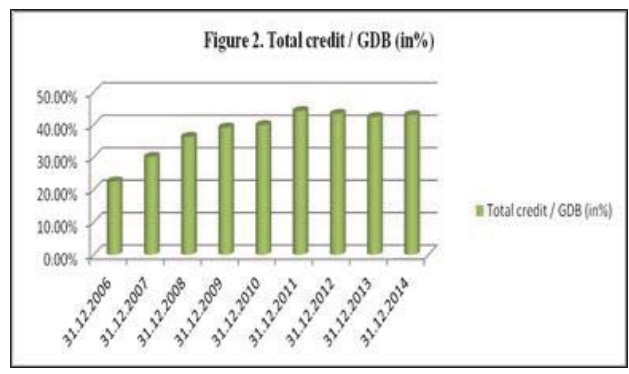


All banks that operate in Albania are under supervision and regulation of the central Bank of Albania. Through supervision, Bank of Albania aims promoting of banking system stability and protection of depositors and the general public interest. Aiming the improvement of financial system functioning and its soundness, Bank of Albania is the institution that has to play a key role on fulfillment of criteria set by Development Policy Loans. These criteria arise from findings of Financial System Assessment Process. Development Policy Loans is an instrument of World Bank that requires fulfillment of certain development criteria as preliminary to grant supporting loans to the Albanian government. As table 2 points out, the total risk-weighted assets and off-balance sheet items has been increasing and in 2014 they grew by ALL 51.6 billion or $8 \%$ compare to previous year. In 2014, all assets classes were up. High-risk assets of weighted coefficient $100 \%$ and $150 \%$ had the highest increase by ALL 35.5 billion (9.4\%) and ALL 14.4 billion (11.9\%), respectively. Risk-weighted off-balance sheet items were down during 2014, by ALL 6.8 billion (17.4\%). Their share appears relatively insignificant, accounting for about $4.7 \%$ of total risk-weighted assets and off-balance sheet items of the banking system at end-2014, down by 1.4 percentage points from a year earlier.

Table 2. Banking system risk-weighted assets

\begin{tabular}{|l|c|c|c|c|c|c|}
\hline Indicators (in ALL million) & Dec 2014 & Dec 2013 & Dec 2012 & Dec 2011 & Dec 2010 & Dec 2009 \\
\hline Risk-free assets (0\%) & $501,218.1$ & $493,820.3$ & $457,736.1$ & $450,321.4$ & $409,673.9$ & $381,448.4$ \\
\hline Low-risk assets(20\%) & $217,116.7$ & $214,915.0$ & $191,600.9$ & $134,820.5$ & $95,701.9$ & $58,545.4$ \\
\hline Moderate-risk assets (50\%) & $24,500.4$ & $23,731.4$ & $27,573.4$ & $31,091.0$ & $34,354.0$ & $32,814.7$ \\
\hline High-risk assets (100\%) & $401,132.8$ & $366,654.7$ & $360,466.0$ & $340,090.6$ & $262,324.9$ & $282,952.7$ \\
\hline Assets risk-weighted at150\% & $135,976.7$ & $121,537.3$ & $137,241.6$ & $152,242.8$ & $178,050.0$ & $118,378.6$ \\
\hline Risk-weighted off-balance sheet items & $32,454.3$ & $39,267.3$ & $25,254.8$ & $21,784.2$ & $20,303.4$ & $14,209.0$ \\
\hline Risk-weighted assets and off-balance sheet items & $\mathbf{6 9 2 , 8 8 9 . 7}$ & $\mathbf{6 4 1 , 2 9 8 . 5}$ & $\mathbf{6 4 3 , 6 9 0 . 1}$ & $\mathbf{6 3 2 , 7 4 8 . 7}$ & $\mathbf{5 8 6 , 0 2 0 . 7}$ & $\mathbf{5 0 2 , 8 4 6 . 6}$ \\
\hline
\end{tabular}

Source: Bank of Albania

In the context of regulations issued by the Bank of Albania, the regulation on capital requirement in 1999 is one of the first. This regulation has been reviewed and some of the standards of Basel II have been adopted. Based on the strategy of the Bank of Albania for gradual transition of regulatory supervisory framework from Basel I to Basel II and approximation with European directives for credit institutions in 2013, regulation "On capital adequacy ratio" was approved and is entered into force in 2015. During 2014, was drafted the regulation "On the bank's regulatory capital" (Bank of Albania, 2014). This regulation addresses also a series of new requirements of Basel III and Capital Requirement Directive IV.

Based on the Medium-Term Development Strategy of the Bank of Albania the developments on the regulatory framework will intend its approximation with Basel II and Basel III principles and the European Union legislation. Figure 3 shows respectively the tendency of capital adequacy for Albanian banking system compared to the limit of $12 \%$ required by the regulator. As in figure 4 the components of capital adequacy ratio, regulatory capital and risk-weighted assets are increased from 2006 and first quarter of 2015. The increase rate is higher for the regulatory capital.
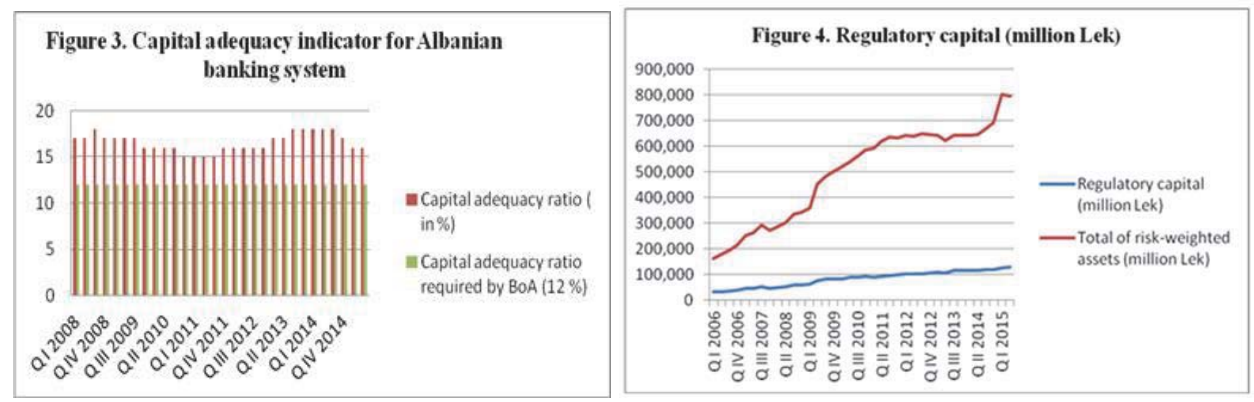

Against the minimum regulatory benchmark of $12 \%$, the Capital Adequacy Ratio (CAR), a key prudential ratio, was $16.8 \%$, at end of 2014. Compared to the same period a year earlier, it was up down by 1.1 percentage points, returning to the trend observed since end -2006 . 
The loan loss provision coverage ratio is an indicator of how protected a bank is against future losses. A higher ratio means the bank can withstand future losses better, including unexpected losses beyond the loan loss provision. Loan loss provisions are important not only to banks but to the broader business community. Loan loss provisions and net charge-offs can serve as useful indicators of the overall health of the economy.

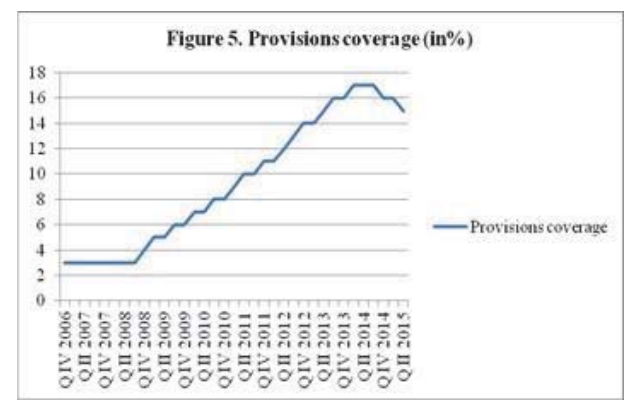

As been present to figure 5, provisions coverage has been increased from 3\% in 2006 to 17\% in 2014 (till end of third quarter). The last quarter of 2014 and first quarter of 2015 provisions coverage is 16 and continuing this moderate decline becomes $15 \%$ in the second quarter of 2015.

Economic and regulatory capital concepts are usually used in the frame of banking capital regulation as proposed by Basel Committee (2004) on banking supervision. The definition of regulatory capital for banks that exercise their activity in Albania is give by the regulation "On the bank's regulatory capital" (2014). This regulation determines the structure of regulatory capital as well as its components and methods of calculation. It also sets its minimum level.

According to this regulation, regulatory capital is bank capital that is used to buffer credit risk, market risk and operational risk. Regulatory capital, based on its characteristics and conditions defined by this regulation, is composed by two categories: a) capital of first level - core capital; b) capital of second level - supplementary capital. Bank's Regulatory capital is calculated as the sum of these two categories taking in consideration discounts applied according to the requirements of this regulation and/or other regulative acts.

The calculation of the regulatory capital should be according to the guideline "On bank's regulatory capital" issued by the Bank of Albania. At any moment the regulatory capital should be more that the sum of: a) capital requirement for credit and counterparty risk. This is calculated as the total of risk weighted exposures multiplied by $12 \%$; $b$ ) capital requirements for market risk multiplied by $1.5 ; c$ ) capital requirement for operational risk multiplied by 1.5 . For the two last components, calculations has to be according to the provisions and methods determined in the regulation "On capital adequacy ratio".

The relationship between risk and capital in the Albanian banking system is a positive and significant one. For the Albanian banking system, Kufo (2015), capital results to be dependent on the risk-taking level and their relation is positive. On the other hand, risk is dependent on the capital level that a bank retains and once again their relationship is positive. Profitability and size of bank do not affect its regulatory capital. Because of high efficiency of the regulator and strong monitoring from him there are no undercapitalized banks in the Albanian banking system. Well-capitalized banks can perform according to the requirements of the regulator without affecting their behavior towards risk and capital.

\section{Conclusions}

This paper reviews theoretical and empirical literature on the efficiency of capital regulation and effects that might have capital regulation on the bank's decision. The theoretical literature on bank regulation and bank's decisions on risk-taking and capital structure gives contradicting results. Modeling framework is subject to criticism.

Capital requirements were supposed to enhance economic growth. Conclusions on the link between them result from researches focused on indirect effects of capital regulation, which in turn can have an impact on economic growth.

Theoretical studies are not conclusive on the effect that more stringent capital requirements have on bank efficiency. Capital requirements enhance financial stability and improve bank efficiency by larger capital used as buffer and by lowering moral hazard. There are also arguments that higher capital requirement may enhance excessive risktaking. Most empirical evidences suggest that more stringent capital regulation may lead to lower riskiness of bank assets because it reduces bank's exposure to systemic risk. On the other hand, there are studies that don't find strong the link 
between capital requirement and bank risk.

Banks can respond to higher risk-weighted capital requirements by raising equity, cutting down lending or reducing asset risk. The way how banks choose to respond to capital requirements really matters. Each of these alternatives gives different impact to economy growth. What is the way that banks operating in Albania react to higher risk-weighted capital requirements and impact that the alternative they choose have to the economic growth will be the object of following papers. The theoretical and empirical literature presented in this paper will support their assessments and explanations of regressions that might be found.

To my knowledge, in Albania there has not been any research on this issue. Albanian banking system is relatively a new system and as such, in general, banks operating in Albania have a capital adequacy ratio above the minimum required by the regulator, Bank of Albania. There has not been any pressure to this ratio because $50 \%$ of assets are in paid loans that is an important component to the capital adequacy ratio. Banks still have reserves of using the maximum of their funds provided by the shareholders, or the funds provided by third parties. Overall our banking system has not suffered almost any lack of liquidity; the more that we are currently in a situation that banks have wrinkled their loan portfolio. For the first time in 2013-2014 there is a decrease on outstanding loans of banking system.

\section{References}

Albertazzi, U., Marchetti, D.J. (2010). Credit Supply, Flight to Quality and Evergreening: An Analysis of Bank-Firm Relationships after Lehman Bank of Italy, Working Paper No. 756

Anderson, R.C., Fraser, D.R. (2000). Corporate control, bank risk-taking, and the health of the banking industry. Journal of Banking and Finance 24, 1383- 1398.

Bank of Albania, 2015. Regulation "On the Bank's Regulatory Capital" [Online] Available: http://www.bankofalbania.org/web/rules_and_ regulations_2799_2.php

Bank of Albania, 2013. Regulation "On Capital Adequacy Ratio". [Online] Available: http://www.bankofalbania.org/web/rules_and_ regulations_2799_2.php

Bank of Albania, 2013-2014. Annual Reports [Online] Available: http://www.bankofalbania.org/web/Annual_Report_new_2611_2.php

Bank of Albania, 2006-2015. Supervision Annual reports 2005-2014 [Online] Available: http://www.bankofalbania.org/web/supervision_ report_new_2614_2.php

Benston, G., Eisenbeis, R., Horvitz, P., Kane, E., \& Kaufman G. (1986). Perspectives on safe and sound banking: Past, Present, and future. MIT Press, Cambridge 1986.

Bernake, B.S., \& Lown, C.S., (1991). The credit crunch. Brookings Papers on Economic Activity 2, $205-247$.

De Haan, J., \& Klomp, J. (2012). Banking risk and regulation: Does one size fit all? Journal of Banking and Finance 36, 3197-3212.

De Jonghe, O. (2010). Back to the basics of banking? A micro analysis of banking system stability. Journal of Financial Intermediation 19, 387-417.

Demsetz, R.S., Saidenber, M.R., \& Strahan Ph. E. (1997). Agency problems and risk taking in banks. Federal Reverve Bank of New York, Research paper No.9709

Dewatripont, M., \& Tirole, J. (1994). The Prudential Regulation of Banks, MIT Press.

Furlong, F.T., and Keeley, M.C. (1989). Capital regulation and bank risk-taking: a note. Journal of Banking and Finance 13, 883-891.

Gambacorta, L., \& Mistrulli, P.E. (2004). Does bank capital affect lending behavior? Journal of Financial Intermediation 13, $436-457$.

Haubrich, J. G., and Wachtel, P. (1993). "Capital Requirements and Shifts in Commercial Bank Portfolios." Federal Reserve Bank of Cleveland Economic Review 29 (third quarter): 2-15.

Huang, R., \& Radnovski, L. (2009). Why Are Canadian Banks More Resilient? IMF Working Paper No. 09/152.

Jensen M.C., \& Meckling, W.H., (1976). Theory of the firm: Managerial behavior, agency costs and ownership structure. Journal of Financial Economics 3 (1976), 305-360

Jimenez, G., Ongena, S., Peydro, J-L., \& Saurina, J. (2012). Credit supply and monetary policy: Identifying the bank balance-sheet channel with loan applications. American Economic Review 102 (5), 2301-2326

Kane, E., (1985). The gathering crisis in federal deposit insurance. MIT Press, Cambridge 1985.

Kane, E., (1989). The S\&L insurance crisis: How did it happen? Washington, DC: Urban Institute Press

Kapan, T., \& Minoiu, C. (2013). Balance sheet strength and bank lending during the global financial crisis. IMF Working Paper 13/102.

Kashyap, A., Stein, J., \& Hanson, S., (2010). An analysis of the impackt of "Sustantially heightened" capital requirements on large financial institutions. Journal of Economic Perspectives 25, 3-28.

Keeley, M.C. (1990). Deposit insurance, risk, and market power in banking. American Economic Review 80 (1990) 1183-1200

Kishan, R., \& Opiela, T., (2000). Bank size, bank capital, and bank lending channel. Journal of Money, credit and banking 32(1), 129-141

Koehn, M., \& Santomero A.M., (1980). Regulation of bank capital and portfolio risk. Journal of finance 35 (1980), 1235-1244.

Kufo, A., 2015. Albanian banking system: Risk behavior and capital requirements. Journal of Applied Economics and Business, Vol. 3 , issue 2 - June, 2015, 5-16.

Marcus, A.J. \& Shaked, I., (1984). The valuation of FDIC deposit insurance using option-pricing estimates. Journal of Money, Credit, and Banking 16 (1984), 446-460. 
Martinez-Miera, D., \& Suarez, J. (2014). Bank's endogenous systemic risk taking. Mimeo

Matten, C. (1996). Managing Bank Capital: capital allocation and performance measurement. (2nd ed.) Chichester: Wiley

Merton, R.C., (1977). An analytic derivation of the cost of deposit insurance loan guarantees. Journal of Banking and Finance 1 (1977), 3-11.

Miles, D., Yang, J., \& Marcheggiano, G. (2012). Optimal bank capital. The Economic Journal 123, 1-37.

Modigliani, F., \& Merton H.M., (1958). The cost of capital, corporation finance and the theory of investment. The American Economic Review, 261-297.

Ronn, E., \& Verma, A.K. (1986): Pricing risk-adjusted deposit insurance: An option-based model. Journal of Finance 41 (1986) $871-894$.

Ross, S.A. (1977): The determination of financial structure: The incentive-signaling approach. Bell Journal of Economics 8 (1997) 23-40.

Santos, J. A.C., (1999). Bank capital and equity investment regulations. Journal of Banking and Finance 23, 1095-1120.

Saunders, A., Strock, E., \& Travlos, N.G. (1990). Ownership structure, deregulation, and bank risk taking. Journal of Finance 45 (1990), 643-654.

Woo, D., (2003). In search of "capital crunch": Supply factors behind the credit slow down in Japan. Journal of Money, Credit and Banking 35(6), 1019-1038. 